\title{
Fungal infection has sublethal effects in a lowland subtropical amphibian population
}

\author{
Laura A. Brannelly ${ }^{1 *}$, Matthew W. H. Chatfield ${ }^{2}$, Julia Sonn ${ }^{3}$, Matthew Robak ${ }^{3}$ and Corinne L. Richards-Zawacki
}

\begin{abstract}
Background: The amphibian chytrid fungus, Batrachochytrium dendrobatidis ( $B d)$, has been implicated as a primary cause of decline in many species around the globe. However, there are some species and populations that are known to become infected in the wild, yet declines have not been observed. Here we conducted a yearlong capture-markrecapture study and a 2-year long disease monitoring study of northern cricket frogs, Acris crepitans, in the lowland subtropical forests of Louisiana.

Results: We found little evidence for an impact of $B d$ infection on survival; however, $B d$ infection did appear to cause sublethal effects, including increased capture probability in the field.

Conclusions: Our study suggests that even in apparently stable populations, where $B d$ does not appear to cause mortality, there may be sublethal effects of infection that can impact a host population's dynamics and structure. Understanding and documenting such sublethal effects of infection on wild, seemingly stable populations is important, particularly for predicting future population declines.
\end{abstract}

Keywords: Capture-mark-recapture, Chytridiomycosis, Disease tolerance, Wildlife disease

\section{Background}

Emerging infectious diseases have become an important factor in understanding wildlife health over the last few decades [1]. Some of the most impactful infectious diseases of wildlife have been fungal, and these have caused catastrophic declines and even extinctions in both plants and animals [2]. The fungal disease chytridiomycosis, caused by the fungal pathogen Batrachochytrium dendrobatidis $(B d)$, affects amphibians specifically and has been named one of the most devastating wildlife diseases in recorded history [3]. Chytridiomycosis is known to have caused population declines in a number of susceptible frog species around the world $[4,5]$. However, less is known about its impacts on less-susceptible species, i.e., those that are infected in the wild but show no evidence of decline due to disease.

Capture-mark-recapture (CMR) studies can be a powerful tool for clarifying the impact of $B d$ infection on wild

\footnotetext{
*Correspondence: laura.brannelly@pitt.edu

${ }^{1}$ Department of Biological Sciences, University of Pittsburgh, Pittsburgh, PA, USA

Full list of author information is available at the end of the article
}

populations [6-11]. CMR studies permit the estimation of survival, capture and infection state change probabilities, and population size through animal capture data and the inclusion of a variety of biotic or abiotic variables [12]. CMR studies on $B d$-susceptible species have been used to demonstrate that even when chytridiomycosis has reached an enzootic state within a population, survival can be substantially reduced in $B d$-infected animals compared to uninfected animals [6-11]. While understanding disease dynamics within susceptible and declining populations is important for conservation purposes $[10,13]$, investigating disease impacts on apparently stable populations is also important for understanding the potential for less dramatic yet still meaningful impacts of this pathogen on host ecology. CMR analyses can be used to estimate whether a population is stable, crashing or rebounding. Furthermore, these analyses can be used to predict which circumstances might lead to disease outbreaks or disease-induced population crashes [14, 15]. To date, limited research has investigated the effects of $B d$ infection on apparently stable host populations.

Acris crepitans, the northern cricket frog, is native to the Southeast, Midwest and Northeast regions of the 
United States. The species is listed as least concern by the IUCN [16], and throughout much of the species' range it is abundant. There have been large scale declines reported, particularly in the subspecies A. c. blanchardi, which were first noticed in 1977 in southern Ontario, Canada, and have since been documented across much of its northern distribution [17]. These declines have been hypothesized to result from habitat modification and loss, habitat acidification, and toxins [18, 19]. $B d$ is known to infect $A$. crepitans in the wild [20-22], and mortality due to chytridiomycosis has been documented ([20]; authors' pers. obs.), but chytridiomycosis has not been directly implicated in the declines that have occurred.

In this study we used field surveys to assess the impact of $B d$ infection on $A$. crepitans from the southern extent of its range in Louisiana. The lowland subtropical population we studied is known to harbor $B d$, but animals remain abundant. We expect impacts of $B d$ to be minimal in this population due to warm summer temperatures in the region, which are outside the thermal optimum for $B d$ growth. Further, $A$. crepitans is a diurnal species [23], which may increase its basking behavior compared to other species in the region thereby reducing infection. We conducted a CMR study of a single population of $A$. crepitans for 1 year in order to assess the impact of $B d$ on the population. We then continued to monitor for an additional year, sampling for infection prevalence and intensity, as well as comparing $B d$ dynamics in this host with that in other amphibian species found at the site. We aimed to determine the impact of $B d$ on survival and capture probability across seasons, as well as compare yearly infection dynamics of $A$. crepitans with other sympatric species to better understand the impacts of $B d$ infection on wild populations.

\section{Methods}

\section{Study site}

We conducted our field study at Tulane University's F. Edward Herbert Research Center in Belle Chasse, Louisiana $\left(29^{\circ} 52^{\prime} 29.4^{\prime \prime} \mathrm{N}, 89^{\circ} 55^{\prime} 16.2^{\prime \prime} \mathrm{W}\right.$, elevation $\left.2 \mathrm{~m}\right)$. The study site was an approximately one acre wooded ephemeral pond $200 \mathrm{~m}$ from a bayou. Acris crepitans at this site are active and breeding year-round [24], whereas other species use the site only when the pond contains water. During each survey the entire pond depression and surrounding wooded area was searched visually and haphazardly for all amphibian species. At least two people searched the site for at least three full hours on each survey day. We sampled frogs at the site twice per month, on 2 non-consecutive days, during daylight. Data from a nearby weather station (Naval Air Station Joint Reserve Base New Orleans, located $9.9 \mathrm{~km} \mathrm{SW}$ of study site) for the corresponding time periods was obtained from Weather Underground, Inc. (The Weather Company, IBM) (Fig. 1).

\section{Seasonal infection prevalence and intensity}

From November 2010 through July 2012, we sampled all post-metamorphic amphibians encountered during our surveys to estimate $B d$ infection intensity and prevalence. We captured each animal with a clean, nitrile-gloved hand and placed it in a new, individual plastic zip bag. Shortly thereafter (within $1 \mathrm{~h}$ ), we swabbed the animal for $B d$ (described below). We placed animals in a cool space away from direct sunlight and released them where they were captured after the survey was complete to avoid capturing an animal twice on the same survey day.

\section{Capture-mark-recapture study}

From November 2010 to November 2011 we sampled $A$. crepitans within the designated study site for capturemark-recapture analysis. After data was collected, as described above, we used a toe tip removal scheme to individually identify each animal $[25,26]$. Toe tips were removed with disinfected surgical blades, where no more than one toe per foot and four toes total were removed per animal. The thumb was never removed. While there has been some recent concern over the use of toe-clipping as a marking method for amphibians, there is no evidence that the marking scheme used in this study causes any more harm than that of temporary handling stress [27-29], and toe-clipping can be the safest and most reliable marking scheme for small amphibian species [26].

While surveys were conducted twice a month, each month's captures were combined together to minimize dispersion of the data. If an individual was captured twice in 1 month, the infection load (measured in zoospore equivalents, or $\mathrm{ZE})$ was averaged $(\mathrm{n}=6)$ between the two samples. If the animal was negative for $B d(\mathrm{n}=25)$, the infection load was equal to $0 \mathrm{ZE}$, therefore if an animal was captured twice and one capture was a positive and the other was a negative, the samples were still averaged $(\mathrm{n}=10)$.

\section{Testing for $B d$}

To test for $B d$, we swabbed (with swab model MW113, Medical Wire and Equipment Co.) each animal's skin five times on each of the dorsum, venter, sides, and undersides of each foot. Swabs were stored dry at $-20{ }^{\circ} \mathrm{C}$ prior to DNA extraction. We extracted genomic DNA from swab samples using the DNeasy Blood and Tissue Kit (Qiagen, Inc.) following the protocol for animal tissue, but with the following modifications: swabs were incubated for $1 \mathrm{~h}$ and were vortexed and spun in a centrifuge once after $30 \mathrm{~min}$ and again at the end of the incubation 



Fig. 1 Monthly averages of weather variables. Air temperature (a), relative humidity (b), barometric pressure (c), and cumulative monthly rainfall (d) as measured by the nearest weather station (9.9 km SW of field site), from November 2010-November 2011. Daily mean is in black, maximum is in red, and minimum is in blue

period, and samples were eluted twice using $100 \mu \mathrm{L}$ of elution buffer each time for a final elution volume of $200 \mu \mathrm{L}$. We then used a quantitative polymerase chain reaction (qPCR, Applied Biosystems) assay to detect and quantify $B d$ DNA in these extracts. Our assay followed Boyle et al. [30] with the following modifications: we did not dilute the DNA extracts and included both an internal positive control [31] and bovine serum albumin (BSA) [32] in each reaction well. Each run contained positive and negative controls (extracted from swabs of known $B d$-positive and $B d$-negative captive Rana catesbeiana) and a five-fold dilution series of standards made using a solution of zoospores of the JEL423 $B d$ isolate. We tested each extract only once (singlicate) to maximize cost effectiveness [6,33], and considered a sample positive for $B d$ if the qPCR indicated $>1 \mathrm{ZE}$ in the reaction. $\mathrm{ZE}$ was calculated as the number of zoospores present in the whole extract (whole swab value).

\section{Analysis}

\section{Infection dynamics}

To test for differences in infection prevalence (the proportion of infected individuals) and intensity (the pathogen load, or ZE calculated from the qPCR results) in $A$. crepitans over time, we used qPCR results from the full 22 months of surveys (10 months beyond the end of the CMR study). To test for variation in infection prevalence across months and years we used a generalized linear mixed model (GLMM) using a binary logistic regression. Infection status ( $B d$-negative/positive) was the dependent variable, and month, year and the interaction between month and year were fixed effects. Individual ID was included as a random effect (Additional file 1).

To test for differences in infection intensity of $B d$-positive $A$. crepitans over time we used a mixed effects model, and we used only $B d$-positive captures in this analysis. Zoospore equivalents were $\log _{10}$ transformed, and this was the dependent variable. Month and year of capture and their interaction were included as fixed effects in the model, and individual ID was a random effect.

We also tested for differences in pathogen load among species over the same survey period. Some species had few positive animals so infection intensity and prevalence were combined to assess pathogen load. Pathogen load was analyzed among species including both the positive and negative animals of each species. We conducted a 
GLM where infection intensity $\left(\log _{10}(Z E+1)\right)$ was the dependent variable, and fixed factors were year, month and species. A second test was conducted on all species except $A$. crepitans with the same variables. This second test was conducted because there were many more $A$. crepitans collected over the study period, and we wanted to make sure the patterns observed when all species were included were not unduly influenced by the inclusion of this better-sampled species. Species were only included in both of these analyses if at least 10 individuals were captured over the study period (Additional file 2). All of the above analyses were performed in SPSS v21.

\section{Population modeling}

We estimated survival $(\Phi)$, capture (p), and disease state transition $(\Psi)$ probabilities for A. crepitans adult animals using our CMR data of post-metamorphic capture and swab data from the frogs during the 12-month survey period using the Conditional Arnason-Schwarz model in M-SURGE [34]. M-SURGE is a program designed specifically for multi-state CMR studies, and its outputs have been shown to be robust even with low recapture rates [34]. The variables included in our model set were time in months (t), $B d$ state at capture (f), and $B d$ state at previous capture (to). The two disease states were $B d$-positive and $B d$-negative, based on the swab data collected with each capture. In this model, the types of disease state transitions that are predicted are: (1) remain $B d$-negative, (2) become infected (transition from $B d$-negative to $B d$ positive), (3) remain $B d$-positive, and (4) clear infection (transition from $B d$-positive to $B d$-negative). All variables and combinations of variables (additive and multiplicative) were assessed for each term probability in order to generate the best-fit model. We measured goodness of fit ( $\hat{c})$ with the program U-CARE [35] (Additional file 3).

We estimated the population size for A crepitans using a POPAN model [36] in Program MARK [37]. The POPAN model is a formulation of the Jolly-Seber model for CMR analysis that estimates survival and capture rates as well as abundance and recruitment rates. The POPAN model additionally estimates a "superpopulation" size (the theoretical finite populations size estimated via population modeling number-the subpopulation size of the animals exposed to sampling, which represents an estimate of the total population size at a site). The specific probability estimates in the model set were survival probability $(\Phi)$, capture probability (p), and probability of entry into the population $\left(\mathrm{P}_{\text {ent }}\right)$. These estimates are derived from the individual capture data only; they do not account for disease status. Variables that were considered to affect these probabilities were time in months ( $t$ ), or no variable (.). Population (or superpopulation) size was estimated using the best-fit model in
Program MARK. All possible model variables were analyzed separately in order to determine the best-fit model. Data dispersion was assessed using U-CARE, as stated above.

We used Akaike's information criterion (AIC) for model selection, where the best fitting model is indicated by the lowest AIC value, or within two units from the lowest AIC value $(\triangle \mathrm{AIC}<2.0)$. We selected the eight best-fitting models as well as the full (all variables included) model and the null model, and all the models tested that converged for the POPAN model (Table 2).

Model averaging was performed if more than one model was within 2 AIC values of the best fitting model. Model averaging was performed by calculating model weights $[38,39]$ (reported in Table 2), then using the outputs of the best fit models for survival, capture and state change estimates, average model outputs were calculated following the "natural averaging" approach [38].

\section{Results}

\section{Infection dynamics in A. crepitans}

Over 22 months of field surveys (November 2010 to July 2012), we collected skin swabs for $B d$ analysis from 699 capture events of $A$. crepitans. Infection prevalence varied across months (GLMM: Month, $\mathrm{F}_{11,681}=7.63$, $\mathrm{p}<0.01$ ), and there was also a significant interaction between month and year (GLMM: month *year, $\left.\mathrm{F}_{4,681}=5.067, \mathrm{p}<0.01\right)$, but year alone was not a predictor of infection prevalence (GLMM: year, $F_{2,681}=0.351$, $\mathrm{p}=0.704$ ). Prevalence was highest between January and May and lowest between July and November. Infection prevalence was higher January through March of 2012 than for those same months in 2011 (Fig. 2a).

Infection intensity varied across years (mixed effects: year, $\mathrm{F}_{2,206.72}=21.721, \mathrm{p}<0.01$ ) but not months (mixed effects: month, $F_{9,177.53}=1.485 \mathrm{p}=0.16$ ), though the interaction between month and year was also significant (mixed effects: month *year, $\mathrm{F}_{3,202.12}=4.379, \mathrm{p}<0.01$ ). The 2nd year of the survey had a higher mean infection intensity than the first, and this pattern appears to have been driven by an increase in infection intensity in the cooler months (January-May; Fig. 2b).

\section{Infection dynamics in other amphibian hosts}

In addition to the $699 \mathrm{~A}$. crepitans captures described above, we captured 38 Pseudacris fouquettei (Cajun chorus frog), 26 Incilius nebulifer (gulf coast toad), 16 Pseudacris crucifer (spring peeper), 16 Rana sphenocephala (southern leopard frog), and 11 Gastrophryne carolinensis (eastern narrow-mouthed toad) over the course of our study. When all species were included in the analysis, pathogen load differed across months and species (GLM: month, $\mathrm{F}_{11,794}=12.501, \mathrm{p}<0.01$; species, 




$\left.\mathrm{F}_{5,794}=5.413, \mathrm{p}<0.01\right)$ and the interaction between month and species, as well as between month and year were significant (GLM: species * month, $\mathrm{F}_{15,794}=5.009$, $\mathrm{p}<0.01$; month *year, $\left.\mathrm{F}_{5,794}=7.749, \mathrm{p}<0.01\right)$, but year alone and the interaction between year and species and all three factors did not affect pathogen load (GLM: year, $F_{2,794}=0.284, p=0.75$; year "species, $F_{4,794}=0.226$, $\mathrm{p}=0.92$; year"species *month, $\mathrm{F}_{2,94}=0.73, \mathrm{p}=0.482$ ). When $A$. crepitans was not included in the analysis, pathogen load differed across months and the interaction between month and species was significant (GLM: month, $\mathrm{F}_{7,95}=6.196, \mathrm{p}<0.01$; month "species, $\mathrm{F}_{8,95}=2.683, \mathrm{p}=0.013$ ), but main effects of year, species and all other interactions were not significant (GLM: $\mathrm{F}_{<4,95}<0.54, \mathrm{p}>0.75$ in all cases). Acris crepitans had lower infection intensity than some other species, such as $P$. fouquettei. Although our sample size was small, we did not detect $B d$ on any G. carolinensis (Fig. 2c).

\section{Multistate capture-mark-recapture}

We captured 266 individual $A$. crepitans at least once during the CMR portion of the study (Table 1). Fifty of these individuals were recaptured at least one time, and 13 were recaptured twice for a total of 378 capture events between November 2011 and November 2012 (Table 1). Sixty-three capture events were of $B d$ positive animals (Fig. 3a). Analysis of dispersion of the data (goodness of fit) yielded $\hat{c}=0.788$, and as such $\hat{c}$ was not adjusted in the model.

The three best fitting Conditional Arnason-Schwartz models (Table 2) for this study were averaged. The monthly survival estimate $(\Phi)$ was $93.13 \%$ (95\% CI 82.64-100.00\%) for uninfected animals and 92.23\% (95\% CI 64.47-100.00\%) for infected animals.

Month of capture $(t)$ influenced capture probabilities (p), which were lower in the warm months (May, June and July) than in the cool months (December, January and February) of the year (Fig. 3b). The animal's $B d$ state of previous capture (to) affected capture probability as well, where infected animals were more likely to be captured (Fig. 3b).

$B d$ state change probability varied across months $(\mathrm{t})$ and with the animal's $B d$ state at previous (to) and current (f) capture in all three of the best fit models (Table 2; Fig. 3c). $B d$-negative animals had a very high likelihood of remaining $B d$ negative, and $B d$-positive animals had a higher probability of remaining $B d$-positive in the early months of the year (December-June), and a lower probability of remaining $B d$ positive in the fall (September-November). Animals that were infected had a consistent, low likelihood of clearing infection 
Table 1 Summary of the A. crepitans capture-markrecapture data

\begin{tabular}{lc}
\hline CMR data & Instances \\
\hline Data summary & 266 \\
Unique individuals captured & 50 \\
Number of animals recaptured & $315^{\mathrm{a}}$ \\
Positive captures & $63^{\mathrm{a}}$ \\
Negative captures & \\
Disease state change of recapture & \\
Stay negative & 41 \\
Negative to positive & 12 \\
Positive to negative & 6 \\
Stay positive & 4 \\
Negative to positive to negative & 1 \\
\hline a Total number of capture instances, where some individuals are represented
\end{tabular}

more than once

throughout the study, and animals that were $B d$-negative were more likely to become infected in the fall months (September-November).

\section{Population size}

The best fitting POPAN model was $\Phi(.) \mathrm{p}(\mathrm{t}) \mathrm{p}_{\text {ent }}(\mathrm{t})$ (Table 2). Monthly survival ( $\Phi)$ was not influenced by month $(\mathrm{t})$, while both capture probability $(\mathrm{p})$ and monthly entry into the population $\left(\mathrm{p}_{\text {ent }}\right)$ were influenced by month $(t)$. The population size estimate, based on the best fitting model for the survey period, was 1854.33 (95\% CI 1092.28-3323.45). Dispersion analysis of the data showed near perfect dispersion: $\hat{c}=0.979$, and $\hat{c}$ was not adjusted in the model.

\section{Discussion}

In this study our aim was to determine the impact of $B d$ on a lowland subtropical population of $A$. crepitans; a population known to harbor $B d$, but where animals remain abundant. We assessed the survival and capture probability of $A$. crepitans across seasons, as well as compared yearly infection dynamics with other sympatric species to better understand the impacts of $B d$ infection in wild populations. Through the infection dynamics field study, we found that seasonality plays a large role in infection dynamics in A. crepitans, with higher infection load and intensity in the cooler months (January-May), and near zero infection in the warmer months (JulyNovember). In addition to seasonal infection dynamics in A. crepitans, we also found seasonal fluctuation in the

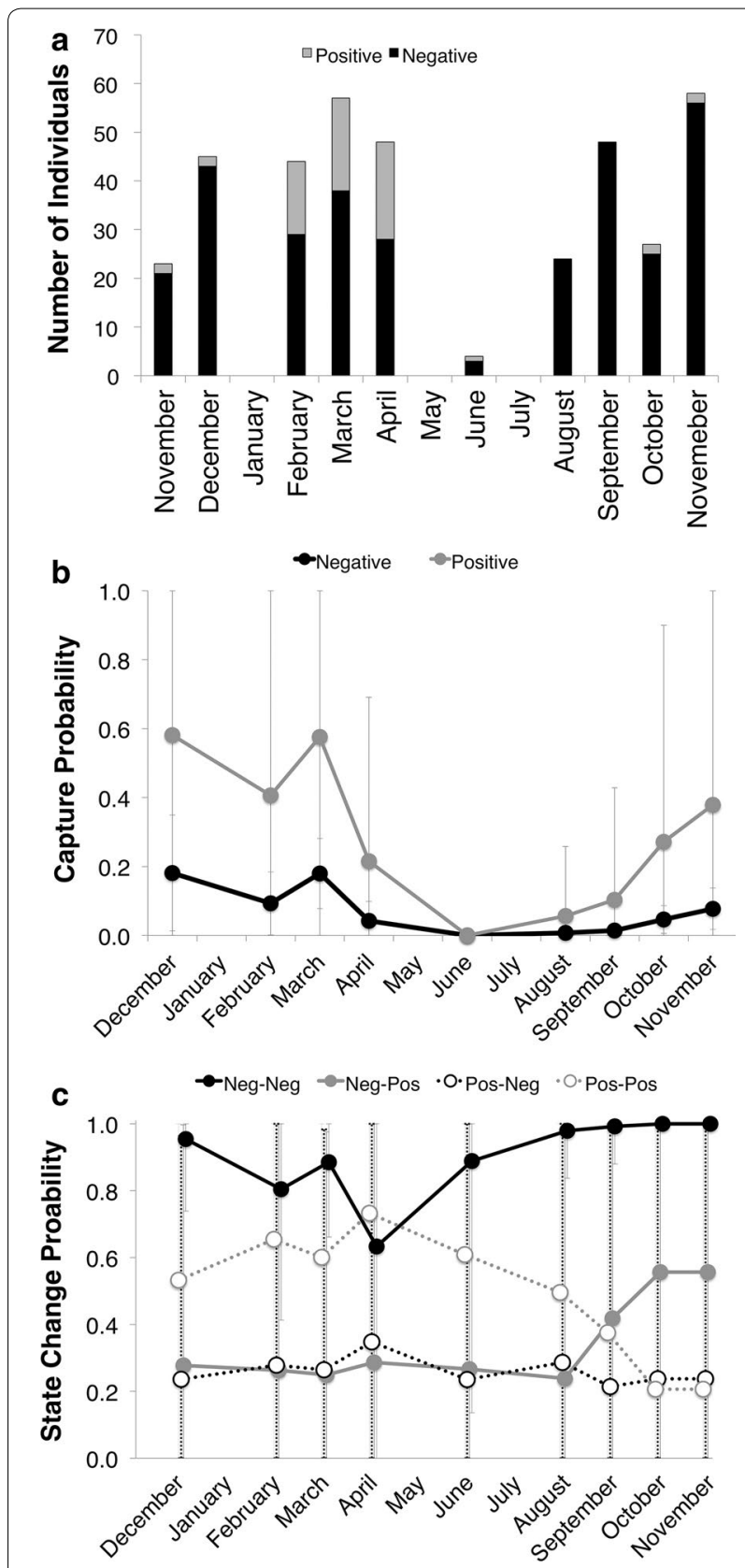

Fig. 3 Capture-mark-recapture results over from November 2010November 2011. Panel a shows the proportion and number of $B d$-positive and-negative $A$. crepitans captured each month of the capture-mark-recapture study. $\mathbf{b}$ Shows monthly capture probabilities after model averaging, where the variables are time and disease state. c Shows $B d$-state change probability, where month, $B d$-state of previous capture, and $B d$-state of capture are included. State change probability is the probability that an individual will change state before the next capture. Four state changes are possible: staying negative (neg-neg), gaining infection (neg-pos), clearing infection (pos-neg), and remaining infected (pos-pos). All error bars indicate 95\% confidence intervals 
Table 2 Best fitting parameterizations of the Conditional Arnason-Schwarz and POPAN Models

\begin{tabular}{|c|c|c|c|c|c|}
\hline Model & \# of parameters & Deviance $^{1}$ & $\mathrm{AIC}^{2}$ & $\Delta \mathrm{AlC}^{3}$ & AIC weights ${ }^{4}$ \\
\hline \multicolumn{6}{|c|}{ Conditional Arnason-Schwarz model ${ }^{a}$} \\
\hline$\Phi() p.($ to $+\mathrm{t}) \Psi\left(f^{*}\right.$ to $\left.+\mathrm{t}\right)$ & 21 & 487.1455 & 529.1455 & 0 & 0.4210 \\
\hline$\Phi() p.(t) \Psi\left(f^{*}\right.$ to $\left.+t\right)$ & 20 & 490.8493 & 530.8493 & 1.7038 & 0.1796 \\
\hline$\Phi(f) p(t o+t) \Psi\left(f^{*}\right.$ to $\left.+t\right)$ & 22 & 487.1309 & 531.1309 & 1.9854 & 0.1560 \\
\hline$\Phi(f) p(t) \Psi\left(f^{*}\right.$ to $\left.+t\right)$ & 21 & 489.683 & 531.683 & 2.5375 & 0.1183 \\
\hline$\Phi(\mathrm{t}) \mathrm{p}(\mathrm{t}) \Psi\left(\mathrm{f}^{*}\right.$ to $\left.+\mathrm{t}\right)$ & 28 & 480.4241 & 532.4241 & 3.2786 & 0.0817 \\
\hline$\Phi() p.(t o+t) \Psi(t)$ & 20 & 495.8178 & 535.8178 & 6.6723 & 0.0150 \\
\hline$\Phi(\mathrm{t}) \mathrm{p}(\mathrm{to}+\mathrm{t}) \Psi\left(\mathrm{f}^{*}\right.$ to $\left.+\mathrm{t}\right)$ & 29 & 477.9171 & 535.9171 & 6.7716 & 0.0143 \\
\hline$\Phi() p.(t o+t) \Psi(i)$ & 12 & 511.9563 & 535.9563 & 6.8108 & 0.0140 \\
\hline$\Phi\left(f^{*} \mathrm{t}\right) \mathrm{p}\left(\mathrm{to}{ }^{*} \mathrm{t}\right) \Psi\left(\mathrm{f}^{*} \mathrm{to} \mathrm{o}^{*} \mathrm{t}\right)$ & 54 & 460.0165 & 546.0165 & 16.871 & 0 \\
\hline$\Phi() p.(.) \Psi()$. & 3 & 581.9903 & 587.9903 & 58.8448 & 0 \\
\hline \multicolumn{6}{|l|}{ POPAN model ${ }^{b}$} \\
\hline$\Phi() p.(t) p_{e n t}(t)$ & 14 & -1028.251 & 417.6716 & 0 & 0.9962 \\
\hline$\Phi(t) p(t) p_{e n t}(t)$ & 20 & -1030.5198 & 428.8351 & 11.1635 & 0.0038 \\
\hline$\Phi(t) p(.) p_{e n t}(t)$ & 15 & -1004.0417 & 444.0828 & 26.4112 & 0 \\
\hline$\Phi() p.(.) p_{\text {ent }}(t)$ & 9 & -962.111 & 473.0152 & 55.3436 & 0 \\
\hline$\Phi() p.(.) p_{\text {ent }}()$. & 3 & $30,658.918$ & $32,081.5399$ & $31,663.8683$ & 0 \\
\hline$\Phi(t) p(t) p_{e n t}()$. & 15 & $30,659.738$ & $32,107.8919$ & $31,690.1903$ & 0 \\
\hline \multicolumn{6}{|c|}{ Italicized terms are AIC values indicating the best fit models } \\
\hline \multicolumn{6}{|c|}{${ }^{1}$ Deviance is a measure for how well the model fits the data } \\
\hline \multicolumn{6}{|c|}{${ }^{2}$ Akaike's information criterion } \\
\hline \multicolumn{6}{|c|}{${ }^{3}$ Change in AIC from the single best fit model } \\
\hline \multicolumn{6}{|c|}{${ }^{4}$ AIC weight is the model probability within the candidate model set } \\
\hline \multicolumn{6}{|c|}{$\begin{array}{l}\text { a Probabilities estimated are survival }(\Phi) \text {, capture }(\mathrm{p}) \text {, and disease state change }(\Psi) \text {; and the variables examined to influence } \Phi, \mathrm{p} \text { and } \Psi \text { were time in months }(\mathrm{t}), B d \\
\text { state at previous capture (to), } B d \text { state of capture }(\mathrm{f}) \text { and no variable }(.)\end{array}$} \\
\hline
\end{tabular}

other sympatric species, where pathogen prevalence varied greatly across months. These results support the seasonality of $B d$ infection dynamics that other studies have demonstrated, presumably because cooler temperatures are better for the pathogen's survival and reproduction $[7,21,40-43]$.

In this study we found higher intensities of infection in A. crepitans in the second year of the survey. Year-toyear fluctuations are also common with this pathogen, which could be due to abiotic factors such as changes in weather patterns (e.g., temperature or rain fall) from year to year. The fluctuations could also be due to biotic factors such as shifts in amphibian population size. In many amphibian species not experiencing declines, population size varies yearly based on recruitment success and other factors [44]. Because $B d$ dynamics have shown densitydependence $[6,8]$, it follows that $B d$ infection dynamics would then vary year-to-year as well [45].

Our comparisons of infection between the species captured suggest that $A$. crepitans has a lower overall pathogen load than the other species surveyed in this study. This result could stem from the overrepresentation of
A. crepitans in our dataset (and thus smaller error bars for this species). Our study design does not permit us to assess which species are driving infection dynamics in this community. The mechanisms of pathogen transmission in the amphibian- $B d$ system [46, 47], and in particular what maintains pathogen presence following warm summer months when the animals appear to clear infection, remain unclear. It is possible that there is an environmental reservoir for $B d$, but the type of long-term environmentally-stable life stage needed to enable this has so far not been detected for this pathogen [48].

A second major aim of this study was to understand the impacts of $B d$ infection on wild animals in the lowland subtropics, where some species are known to harbor $B d$ infection but remain abundant. We used CMR analysis to estimate the effects of $B d$ exposure on survival, capture and disease state change probability in a wild population of $A$. crepitans. For estimates of survival, we found that while disease state was a variable in one of the best fitting models, the monthly survival values were nearly identical for infected and uninfected animals $(<1 \%$ difference in estimated mean monthly survival), with wide and 
overlapping 95\% confidence intervals. The small mean difference in estimated survival, suggests that the difference in survival between infected and uninfected animals is not biologically meaningful $[49,50]$. What is noteworthy about these survival estimates is they demonstrate that $A$. crepitans has a high monthly survival probability ( 0.93), which suggests that the annual survival is on the order of $\sim 0.419$. In more northern populations, A. crepitans is known to have low annual survival, with complete population turnover occurring between 16 and 24 months $[51,52]$. In the subtropical lowlands amphibians do not undergo periods of prolonged cold temperatures, and perhaps this contributes to higher annual survival rates.

While we found little to no support for an effect of infection status on survival probability, we did find evidence for sublethal effects of infection. Through our CMR study we found that while capture rates vary seasonally, there is also a higher capture probability for infected animals than for $B d$-negative animals. This result suggests that $B d$ infection may cause the animals to alter their behavior in some way that makes them easier to capture. Other CMR studies investigating $B d$-host dynamics have similarly found that infected animals were more likely to be captured, and even more so when pathogen load is high $[6,7,9]$.

There have been few documented instances of sublethal effects of $B d$ infection on populations and species that are not experiencing mortality due to $B d$. When individuals that do not succumb to chytridiomycosis are exposed to $B d$, and either tolerate infection or clear infection, the immune system is activated [53-55]. As the immune system is activated, there should be measurable sublethal effects of infection. While there has been considerable research devoted to amphibian immune function in susceptible and non-susceptible hosts (e.g., [56-59], there are few studies that measure the sublethal effects of $B d$ infection on less susceptible or resistant hosts. Weight loss after $B d$ infection but without mortality has been demonstrated in a newt species, Lissotriton helveticus, [60] and the European common frog, $R$. temporaria [61]. There is a decrease in reproductive effort following infection in newts, L. helveticus [60], and, in adult leopard frogs, $R$. pipiens, there is a decrease in jumping ability following exposure to $B d$ [62]. These documented physiological changes after exposure to $B d$ may result in behavioral changes such as reduced escape behavior. In tadpoles, exposure to $B d$ has been shown to cause changes in anti-predator behavior [63, 64]. The differences in capture probability observed in this study between infected and uninfected individuals, particularly in the cold months of the year when infection is much higher, may be due to changes in physiology or behavior as a result of infection. Such sublethal effects from stressors such as infection could lead to changes in individual fitness such as reduced growth, foraging ability, and reproduction [65-67], which could ultimately change population dynamics in subtle ways over time.

The seasonal variation in capture probability that we observed, with lower capture rates in the warmer months than in the cooler months, is typical of subtropical amphibians [68]. These shifts in capture probability appear to occur when temperatures begin to warm and barometric pressure is low (Fig. 1). In the subtropical lowlands of Louisiana, summer months are hot and can be dry, particularly during the heat of the day, leading amphibians to aestivate [69], which would decrease capture probabilities. Amphibian activity is often linked with ideal temperatures and rainfall, and in the subtropics, frog activity is often opposite to that of temperate frogs, which are active during the summer and hibernate during the winter.

The state change probabilities we observed match the seasonality of $B d$ infection. There is a higher likelihood of remaining $B d$-positive between December and June (Fig. 3c) when infection prevalence is high (Fig. 2b, c), and a lower likelihood of maintaining infection in the fall (September-November). After model averaging the 95\% confidence intervals for state change probability remained large. This could be due to the few animals recaptured with $B d$ infection (Table 1). However, the error bars are smaller for the probability of remaining $B d$-negative, and the seasonal pattern supports what is known about the seasonality of $B d$ infection; animals are less likely to be $B d$-negative in the spring (MarchApril) when temperatures are cool, and more likely to be $B d$-negative free in the fall (August-November) after the heat of the summer in subtropical environments $[7,21,40,41]$.

While infection status appears to have impacted capture probability in this $A$. crepitans population, we found no evidence that it impacted survival. The model-averaged estimates for survival in $B d$-positive and $B d$-negative animals are very close in value and their confidence intervals show a large degree of overlap. Given this, we find no evidence for an effect of $B d$ infection on survival in this population. Lowland subtropical habitats often have shorter periods of infection [70], which might lead to infected animals clearing infection before they succumb to disease, and thus minimize direct impacts on survival, but still cause sublethal effects of infection.

Acris crepitans has declined in parts of its range, particularly in the northern regions. While $B d$ has not been specifically implicated in the declines that occurred, this frog species is known to be susceptible 
to chytridiomycosis under certain conditions [71]. Our results suggest that in this subtropical population $B d$ is not affecting survival, but may have sublethal effects in the form of changes to behavior of infected animals.

\section{Conclusions}

Our study aimed to determine the impact of fungal infection on a frog population where disease is endemic, but animals apparently remain abundant. Through our capture-mark-recapture analysis we found that in a lowland subtropical population of $A$. crepitans there was little effect of $B d$ on survival. However, there was a clear difference in capture probability, which may indicate a shift in behavior as a result of infection. Evidence for sublethal effects of $B d$ infection is rare in wild populations not experiencing mortality, and finding it here suggests that $B d$ may be impacting $A$. crepitans in populations that remain abundant and where no reported declines are occurring. Because amphibians are declining globally, monitoring seemingly stable populations is important, especially for a species that has declined elsewhere. Our work demonstrates that while survivorship may not be impacted by disease, behavior can be, which may lead to subtle shifts in population dynamics over time.

\section{Additional files}

Additional file 1. Capture details for each Acris crepitans captured in the study.

Additional file 2. The swab results of all species except Acris crepitans.

Additional file 3. Capture mark recapture with columns representing dates of capture and rows representing individuals.

\section{Authors' contributions}

MWHC and CLRZ conceived and designed the experiments, MWHC, JS, MR performed the field survey, $L A B$ analyzed the data. CLRZ contributed reagents and materials, $L A B$ wrote the manuscript. All authors contributed to the editing. All authors read and approved the final manuscript.

\section{Author details}

${ }^{1}$ Department of Biological Sciences, University of Pittsburgh, Pittsburgh, PA, USA. ${ }^{2}$ School of Biodiversity Conservation, Unity College, Unity, ME, USA.

${ }^{3}$ Department of Ecology and Evolutionary Biology, Tulane University, New Orleans, LA, USA.

\section{Acknowledgements}

We thank Kaiti Tasker, Nick Croy, Angie Baroffio, Kate Magoon, Kelsey Bain, Xander Rose, Megan McWilliams, Yusan Yang, and Danny Lenger for their help with field and lab work, and Gerardo Martin for assistance with CMR modeling.

\section{Competing interests}

The authors declare that they have no competing interests.

\section{Consent for publication}

Not applicable.

\section{Ethics approval and consent to participate}

This study and its methods were approved by Tulane University's Animal Use and Care Committee (Protocol No. 0391). Permission to collect animals from the wild was granted by the Louisiana Department of Wildlife and Fisheries (Permit Nos. WL-Research-201043 and LNHP-10-030).

\section{Data availability}

Data is available in Additional files 1, 2, 3.

\section{Funding}

This work was supported by a Grant to CLRZ from the Louisiana Board of Regents (Award No. LEQSF (2011-14)-RD-A-26) and by Tulane University.

\section{Publisher's Note}

Springer Nature remains neutral with regard to jurisdictional claims in published maps and institutional affiliations.

Received: 13 November 2017 Accepted: 3 September 2018

Published online: 14 September 2018

\section{References}

1. Daszak P, Cunningham A, Hyatt A. Emerging infectious diseases of wildlife-threats to biodiversity and human health. Science. 2000;287:443-9.

2. Fisher MC, Henk DA, Briggs CJ, Brownstein JS, Madoff LC, MCCraw SL, et al. Emerging fungal threats to animal, plant and ecosystem health. Nature. 2012;484:186-94.

3. Skerratt LF, Berger L, Speare R, Cashins S, McDonald KR, Phillott AD, et al. Spread of chytridiomycosis has caused the rapid global decline and extinction of frogs. EcoHealth. 2007:4:125-34.

4. Berger L, Speare R, Daszak P, Green DE, Cunningham AA, Goggin CL, et al. Chytridiomycosis causes amphibian mortality associated with population declines in the rain forests of Australia and Central America. PNAS. 1998:95:9031-6.

5. Lips KR, Brem F, Brenes R, Reeve JD, Alford RA, Voyles J, et al. Emerging infectious disease and the loss of biodiversity in a neotropical amphibian community. PNAS. 2006;103:3165-70.

6. Brannelly LA, Hunter DA, Lenger D, Scheele BC, Skerratt LF, Berger L. Dynamics of chytridiomycosis during the breeding season in an Australian alpine amphibian. PLOS ONE. 2015;10:e0143629.

7. Phillott AD, Grogan LF, Cashins SD, Mcdonald KR, Berger L, Skerratt LF. Chytridiomycosis and seasonal mortality of tropical stream-associated frogs 15 years after introduction of Batrachochytrium dendrobatidis. Conserv Biol. 2013;27:1058-68.

8. Briggs CJ, Knapp RA, Vredenburg VT. Enzootic and epizootic dynamics of the chytrid fungal pathogen of amphibians. PNAS. 2010;107:9695-700.

9. Murray KA, Skerratt LF, Speare R, McCallum H. Impact and dynamics of disease in species threatened by the amphibian chytrid fungus, Batrachochytrium dendrobatidis. Conserv Biol. 2009;23:1242-52.

10. Brannelly LA, Hunter DA, Skerratt LF, Scheele BC, Lenger D, McFadden MS, et al. Chytrid infection and post-release fitness in the reintroduction of an endangered alpine tree frog. Anim Conserv. 2016;19:153-62.

11. Muths E, Scherer RD, Pilliod DS. Compensatory effects of recruitment and survival when amphibian populations are perturbed by disease. J Appl Ecol. 2011;48:873-9.

12. Schmidt BR, Feldmann R, Schaub M. Demographic processes underlying population growth and decline in Salamandra salamandra. Conserv Biol. 2005;19:1149-56.

13. Stegen G, Pasmans F, Schmidt BR, Rouffaer O, Van Praet S, Schaub M, et al. Drivers of salamander extirpation mediated by Batrachochytrium salamandrivorans. Nature. 2017;544:353-8.

14. Valenzuela-Sánchez A, Soto-Azat C, Schmidt BR, Uribe-Rivera DE, Costas F, Cunningham AA. Cryptic disease-induced mortality may cause host extinction in an apparently stable host-parasite system. Proc R Soc B. 2017;284:20171176.

15. Spitzen-van der Sluijs A, Canessa S, Martel A, Pasmans F. Fragile coexistance of the global chytrid pathogen with amphibian populations is mediated by environment and demography. Proc R Soc B. 2017:284:20171444. 
16. Hammerson G, Santos-Barrera G, Church D. Acris crepitans. The IUCN Red List of Threatened Species 2004. 2004;e,T55286A11272584.

17. Gray RH, Brown LE. Decline of northern cricket frogs (Acris crepitans). In: Lannoo MJ, editor. Amphibian declines: the conservation status of United States species. Berkley: University of California Press; 2005. p. 47-54.

18. Beasley VR, Faeh SA, Wikoff B, Staehle C, Eisold J, Schotthoefer AM, et al. Risk factors and declines in northern cricket frogs (Acris crepitans). In: Lannoo MJ, editor. Amphibian declines: the conservation status of United States species. Berkeley: University of California Press; 2005. p. 75-86.

19. Lehtinen RM, Skinner AA. The enigmatic decline of Blachard's cricket frog (Acris crepitans blanchardi): a test of the habitat acidification hypothesis. Copeia. 2006;2006:159-67.

20. Rothermel BB, Walls SSC, Mitchell JCJ, Dodd CK, Irwin LLK, Green DDE, et al. Widespread occurrence of the amphibian chytrid fungus Batrachochytrium dendrobatidis in the southeastern USA. Dis Aquat Organ. 2008;82:3-18.

21. Brannelly LA, Chatfield MWH, Richards-Zawacki CL. Field and laboratory studies of the susceptibility of the green treefrog (Hyla cinerea) to Batrachochytrium dendrobatidis infection. PLoS ONE. 2012;7:e38473.

22. Steiner SL, Lehtinen RM. Occurrence of the amphibian pathogen Batrachochytrium dendrobatidis in Blanchard's cricket frog (Acris crepitans blanchardi) in the US midwest. Herpetol Rev. 2008;39:193-6.

23. Rowley JJL, Alford RA. Hot bodies protect amphibians against chytrid infection in nature. Sci Rep. 2013;3:1515

24. Bayless LE. Post-metamorphic growth of Acris crepitans. Am Midl Nat. 1969:81:590-2.

25. Hero J-M. A simple code for toe clipping anurans. Herpetol Rev. 1989;20:66-7

26. Brannelly LA, Berger L, Skerratt LF. Comparison of three widely used marking techniques on adult anuran species Litoria verreauxii alpina. Herpetol Conserv Biol. 2014:9:428-35.

27. Fisher KJ, Guilfoyle KJ, Hatch KA. Stress induced by toe-clipping in cane toads (Rhinella marina). Copeia. 2013;2013:539-42.

28. Perry G, Wallace MC, Perry D, Curzer H, Muhlberger P. Toe clipping of amphibians and reptiles: science, ethics, and the law. J Herpetol. 2011:45:547-55.

29. Phillott AD, Skerratt LF, McDonald KR, Lemckert FL, Hines HB, Clarke JM, et al. Toe-clipping as an acceptable method of identifying individual anurans in mark recapture studies. Herpetol Rev. 2007;38:305-8.

30. Boyle DG, Boyle DB, Olsen V, Morgan JAT, Hyatt AD. Rapid quantitative detection of chytridiomycosis (Batrachochytrium dendrobatidis) in amphibian samples using real-time Taqman PCR assay. Dis Aquat Organ. 2004;60:141-8.

31. Hyatt AD, Boyle DG, Olsen V, Boyle DB, Berger L, Obendorf D, et al. Diagnostic assays and sampling protocols for the detection of Batrachochytrium dendrobatidis. Dis Aquat Organ. 2007;73:175-92.

32. Garland S, Wood J, Skerratt LF. Comparison of sensitivity between realtime detection of a TaqMan assay for Batrachochytrium dendrobatidis and conventional detection. Dis Aquat Organ. 2011;94:101-5.

33. Kriger KM, Hero J-M, Ashton KJ. Cost efficiency in the detection of chytridiomycosis using PCR assay. Dis Aquat Organ. 2006;71:149-54.

34. Choquet R, Reboulet A-M, Pradel R, Gimenez O, Lebreton J-D. M-SURGE: new software specifically designed for multistate capture-recapture models. Anim Biodivers Conserv. 2004;21:207-15.

35. Choquet R, Lebreton J-D, Gimenez O, Reboulet A-M, Pradel R. U-CARE: utilities for performing goodness of fit tests and manipulating CAptureREcapture data. Ecography. 2009;32:1071-4.

36. Schwarz CJ, Arnason AN. A general methodology for the analysis of capture-recapture experiments in open populations. Biometrics. 1996:52:860-73.

37. White GC, Burnham KP. Program MARK: survival estimation from populations of marked animals. Bird Study. 1999;46:S120-39.

38. Symonds MRE, Moussalli A. A brief guide to model selection, multimodel inference and model averaging in behavioural ecology using Akaike's information criterion. Behav Ecol Sociobiol. 2011;65:13-21.

39. Johnson JB, Omland KS. Model selection in ecology and evolution. Trends Ecol Evol. 2004;19:100-8.

40. Kriger KM, Hero J-M. The chytrid fungus Batrachochytrium dendrobatidis is non-randomly distributed across amphibian breeding habitats. Divers Distrib. 2007;13:781-8.
41. Woodhams DC, Alford RA. Ecology of chytridiomycosis in rainforest stream frog assemblages of tropical Queensland. Conserv Biol. 2005:19:1449-559.

42. Piotrowski JS, Annis SL, Longcore JE. Physiology of Batrachochytrium dendrobatidis, a chytrid pathogen of amphibians. Mycologia. 2004;96:9-15.

43. Berger L, Speare R, Hines HB, Marantelli G, Hyatt AD, McDonald KR, et al. Effect of season and temperature on mortality in amphibians due to chytridiomycosis. Aust Vet J. 2004;82:434-9.

44. Alford RA, Richards SJ. Global amphibian declines: a problem in applied ecology. Annu Rev Ecol Syst. 1999;30:133-65.

45. Brannelly LA, Webb RJ, Hunter DA, Clemann N, Howard K, Skerratt LF, et al. Non-declining amphibians can be important reservoir hosts for amphibian chytrid fungus. Anim Conserv. 2018;21:91-101.

46. Pasmans F, Canessa S, Martel A. The eye of the storm: silent infection driving amphibian declines. Anim Conserv. 2018;21:102-3.

47. Brannelly LA, Clemann N, Skerratt LF, Webb RJ, Berger L, Scheele BC. Investigating community disease dynamics can lead to more effective conservation efforts. Anim Conserv. 2018;21:108-9.

48. Berger L, Hyatt AD, Speare R, Longcore JE. Life cycle stages of the amphibian chytrid Batrachochytrium dendrobatidis. Dis Aquat Organ. 2005;68:51-63.

49. Furuya Y, Wijesundara DK, Neeman T, Metzger DW. Use and misuse of statistical significance in survival analyses. MBio. 2014;5:e00904-14.

50. Cooch E, White G. Program MARK: a gentle introduction. Fort Collins: Colorado State University; 2006.

51. Burkett RD. An ecological study of the cricket frog, Acris crepitans. In: Siegel RA, Hunt LE, Knight JL, Malaret L, Zuschlag NLZ, editors. Vertebrate ecology and systematics. Lawerence: The University of Kansas; 1984. p. 89-103.

52. Gray RH. Seasonal, annual and geographic variation in color morph frequencies of the cricket frog, Acris crepitans, in Illinois. Copeia. 1983;6:300-11

53. Rosenblum EB, Poorten TJ, Settles M, Murdoch GK. Only skin deep: shared genetic response to the deadly chytrid fungus in susceptible frog species. Mol Ecol. 2012;21:3110-20.

54. Poorten T, Rosenblum E. Comparative study of host response to chytridiomycosis in a susceptible and a resistant toad species. Mol Ecol. 2016:25:5663-79.

55. Savage AE, Terrell KA, Gratwicke B, Mattheus NM, Augustine L, Fleischer $\mathrm{RC}$. Reduced immune function predicts disease susceptibility in frogs infected with a deadly fungal pathogen. Conserv Physiol. 2016;4:Cow011.

56. Brannelly LA, Webb RJ, Skerratt LF, Berger L. Effects of chytridiomycosis on hematopoietic tissue in the spleen, kidney and bone marrow in three diverse amphibian species. Pathog Dis. 2016;74:ftw069.

57. Brannelly LA, Roberts AA, Skerratt LF, Berger L. Epidermal cell death in frogs with chytridiomycosis. PeerJ. 2017;5:e2925.

58. Ellison AR, Savage AE, Direnzo GV, Langhammer P, Lips KR, Zamudio KR. Fighting a losing battle: vigorous immune response countered by pathogen suppression of host defenses in the chytridiomycosis-susceptible frog Atelopus zeteki. G3 Genes Genomics Genet. 2014;4:1275-89.

59. Rollins-Smith LA, Ramsey JP, Pask JD, Reinert LK, Woodhams DC. Amphibian immune defenses against chytridiomycosis: impacts of changing environments. Integr Comp Biol. 2011;51:552-62.

60. Cheatsazan H, de Almedia APLG, Russell AF, Bonneaud C. Experimental evidence for a cost of resistance to the fungal pathogen, Batrachochytrium dendrobatidis, for the palmate newt, Lissotriton helveticus. BMC Ecol. 2013:13:27.

61. Bielby J, Fisher MC, Clare FC, Rosa GM, Garner TWJ. Host species vary in infection probability, sub-lethal effects and costs of immune response when exposed to an amphibian parasite. Sci Rep. 2015;5:10828.

62. Chatfield MWH, Brannelly LA, Robak MJ, Freeborn L, Lailvaux SP, RichardsZawacki CL. Fitness consequences of infection by Batrachochytrium dendrobatidis in northern leopard frogs (Lithobates pipiens). EcoHealth. 2013:10:90-8.

63. Parris MJ, Reese E, Storfer A. Antipredator behavior of chytridiomycosisinfected northern leopard frog (Rana pipiens) tadpoles. Can J Zool. 2006;84:58-65

64. Han BA, Searle CL, Blaustein AR, Kilhara S, Bixby R. Effects of an infectious fungus, Batrachochytrium dendrobatidis, on amphibian predator-prey interactions. PLOS ONE. 2011;6:e16675. 
65. Nunn CL, Altizer S. Infectious diseases in primates: behavior, ecology and evolution. New York City: Oxford University Press; 2006.

66. Sheriff MJ, Krebs CJ, Boonstra R. The sensitive hare: sublethal effects of predator stress on reproduction in snowshoe hares. J Anim Ecol. 2009;78:1249-58.

67. Lashkari M, Sahragard A, Ghadamyari M. Sublethal effects of imidacloprid and pymetrozine on population growth parameters of cabbage aphid, Brevicoryne brassicae on rapeseed, Brassica napus L. Insect Sci. 2007;14:207-12.

68. Chang Y, Lucy Hou P. Thermal acclimation of metabolic rate may be seasonally dependent in the subtropical anuran Latouche's Frog (Rana latouchii, Boulenger). Physiol Biochem Zool Ecol Evol Approaches. 2005;78:947-55.

69. Waller JE. Aestivating reptiles and amphibians detected during a littoral March habitat enhancement project at lake Okeechobee, Florida. Florida Sci. 2009;72:171-8.

70. Kriger KM, Hero J-M. Altitudinal distribution of chytrid (Batrachochytrium dendrobatidis) infection in subtropical Australian frogs. Austral Ecol. 2008;33:1022-32.

71. Sonn JM, Berman S, Richards-Zawacki CL. The influence of temperature on chytridiomycosis in vivo. EcoHealth. 2017;14:762-70.
Ready to submit your research? Choose BMC and benefit from:

- fast, convenient online submission

- thorough peer review by experienced researchers in your field

- rapid publication on acceptance

- support for research data, including large and complex data types

- gold Open Access which fosters wider collaboration and increased citations

- maximum visibility for your research: over 100M website views per year

At BMC, research is always in progress.

Learn more biomedcentral.com/submissions 